\title{
Effect of Temperature on and Histopathology of the Interaction Between Meloidogyne incognita and Thielaviopsis basicola on Cotton
}

\author{
N. R. Walker, T. L. Kirkpatrick, and C. S. Rothrock
}

First and third authors: Department of Plant Pathology, University of Arkansas, Fayetteville 72701; and second author: Department of Plant Pathology, University of Arkansas, Southwest Research and Extension Center, Hope 71801.

Accepted for publication 27 April 1999.

\begin{abstract}
Walker, N. R., Kirkpatrick, T. L., and Rothrock, C. S. 1999. Effect of temperature on and histopathology of the interaction between Meloidogyne incognita and Thielaviopsis basicola on cotton. Phytopathology 89:613-617.

Controlled environments were used to study the relationship between the root-knot nematode (Meloidogyne incognita) and Thielaviopsis basicola on cotton. Temperature treatments were continuous 20,24 , and $28^{\circ} \mathrm{C}$ or two cyclic linear regimes with ranges of 14 to 32 or 18 to $28^{\circ} \mathrm{C}$ over $24 \mathrm{~h}$. Cotton seeds were planted in fumigated soil infested with T. basicola, M. incognita, or both. After 42 days, pathogen effects on plant growth and pathogen development were evaluated. Histology was conducted on roots collected 14,28 , and 42 days after planting in the continuous $24^{\circ} \mathrm{C}$ treatment. Reductions in plant height-to-node ratio and total fresh weight were observed for soils infested with both pathogens compared with the control or with soils infested with either pathogen, except for $M$. incognita-infested soil at $28^{\circ} \mathrm{C}$. T. basicola reduced root galling

and reproduction of the nematode at all temperatures. Vascular discoloration caused by $T$. basicola was greater in the presence of $M$. incognita compared with that by $T$. basicola alone. At 2 and 4 weeks, histological studies showed that plants grown in all T. basicola-infested soils contained chlamydospore chains on the root surface and in cortical cells. The fungus was not observed inside the vascular cylinder. Roots from 4-week-old plants from soils infested with $T$. basicola and M. incognita showed fungal sporulation in vascular tissue and localized necrosis of vascular tissue adjacent to the nematodes. At 6 weeks, plants grown in soil infested with T. basicola alone exhibited no remaining cortical tissue and no evidence of vascular colonization by the fungus. Six-week-old plants grown in $T$. basicola $+M$. incognita-infested soils exhibited extensive vascular necrosis and sporulation within vascular tissue. These studies suggest that coinfection expands the temperature ranges at which the pathogens are able to cause plant damage. Further, $M$. incognita greatly increases the access of $T$. basicola to vascular tissue.
\end{abstract}

The root-knot nematode Meloidogyne incognita (Kofoid \& White) Chitwood is a serious pathogen of cotton (Gossypium hirsutum L.) throughout the U.S. cotton belt (1). The soilborne fungus Thielaviopsis basicola (Berk. \& Broome) Ferraris (=Chalara elegans Nag Raj \& Kendrick) is the causal organism of black root rot of cotton, a seedling disease that is characterized by severe rotting of the cortex of young cotton hypocotyls and roots. The pathogen has been reported from many cotton-growing regions (7). Both $M$. incognita and $T$. basicola have been found widely distributed in cotton fields throughout the Mississippi River Delta in Arkansas $(11,16,18)$.

$M$. incognita juveniles enter the root behind the root cap and migrate inter- and intracellularly to the developing vascular tissue. Once established in the vascular tissue, the nematode establishes a feeding site and elicits a variety of changes in the host root including hypertrophy and hyperplasia of root cortical cells. The life cycle of the nematode is favored by warm soil temperatures (4). $M$. incognita-infected plants are typically stunted, slow to mature, and yield less than healthy plants.

T. basicola colonizes the cortical tissue of cotton seedlings, causing a characteristic dark brown to black discoloration of the root and hypocotyl, resulting in stunted, less vigorous plants (22). Black root rot is most severe early in the growing season when soil temperature is below $24^{\circ} \mathrm{C}$ and soil water content is high (17). As soil temperature increases and the plant develops, the infected cortical tissue sloughs off and secondary root growth occurs $(13,14)$. With G. barbadense L., internal colonization of plant vascular tissue may occur, causing a mid- to late-season disease known as internal collar rot (22). However, colonization of $G$. hirsutum vascular tissue rarely

Corresponding author: T. L. Kirkpatrick; E-mail address: tkirkpat@uaex.edu

Publication no. P-1999-0607-01R

(C) 1999 The American Phytopathological Society occurs and likely occurs only when very high populations of $T$. basicola are present (14).

Both the root-knot nematode and T. basicola cause chronic disease problems for cotton producers, and both are ecologically obligate parasites $(8,15)$. Cotton plants infected by either organism alone generally survive but may exhibit decreased growth, delayed maturity, and suppressed yields. However, significant earlyseason cotton seedling mortality can occur when both pathogens are present and environmental conditions favor disease development (21). This association is of concern because the two organisms are frequently found together in fields throughout Arkansas (19).

The association between these organisms on cotton has only recently been documented (21), and there is no information on the effects of temperature on the interaction. Further, histological studies examining the effects of coinfections are lacking for these two organisms. The objective of this study was to determine the influence of temperature on the interaction between these two pathogens. In addition, the relationship between $M$. incognita and T. basicola on cotton roots was examined.

\section{MATERIALS AND METHODS}

Temperature study. Smithdale fine, sandy loam soil was screened (1- $\mathrm{cm}^{2}$ opening) and fumigated with methyl bromide $\left(100 \mathrm{~g} / \mathrm{m}^{2}\right)$ 8 weeks prior to use. Inoculum of T. basicola consisted of chlamydospores harvested from 6-week-old cultures grown on 10\% carrot juice agar (2). Chlamydospore chains were harvested from plates in deionized water with a rubber scraper and digested with chitinase to obtain single chlamydospores (2). Inoculum of $M$. incognita race 3 was obtained from stock cultures maintained in a greenhouse on tomato (Lycopersicon esculentum Mill. 'Rutgers'). Nematode inoculum was prepared by extracting eggs from infected tomato root systems in $0.05 \% \mathrm{NaOCl}(9)$ for $3 \mathrm{~min}$. Soil was infested by di- 
luting inoculum in $50 \mathrm{ml}$ of deionized water and mixing the suspension into soil.

Ten seeds of the root-knot-susceptible cv. Deltapine 50 were planted in pots containing 1,500 g of soil infested with 100 chlamydospores of T. basicola per $\mathrm{g}$ of soil, $10 \mathrm{M}$. incognita eggs per $\mathrm{g}$ of soil, or both. Noninfested pots served as controls. Pots were placed in a growth chamber with a 12 -h photoperiod at a continuous temperature regime of 20,24 , or $28^{\circ} \mathrm{C}$ or two cyclic linear regimes in which temperatures ranged between 14 to 32 or 18 to $28^{\circ} \mathrm{C}$ in $24 \mathrm{~h}$. Pots were separated by watering trays to prevent contamination and were bottom-watered. Fourteen days after planting, plants were arbitrarily removed to leave five plants per pot. Each chamber contained five replications of each treatment in a randomized complete block design. The entire study was repeated once and was terminated after 42 days. Following termination, plants were removed from soil, washed under running tap water to

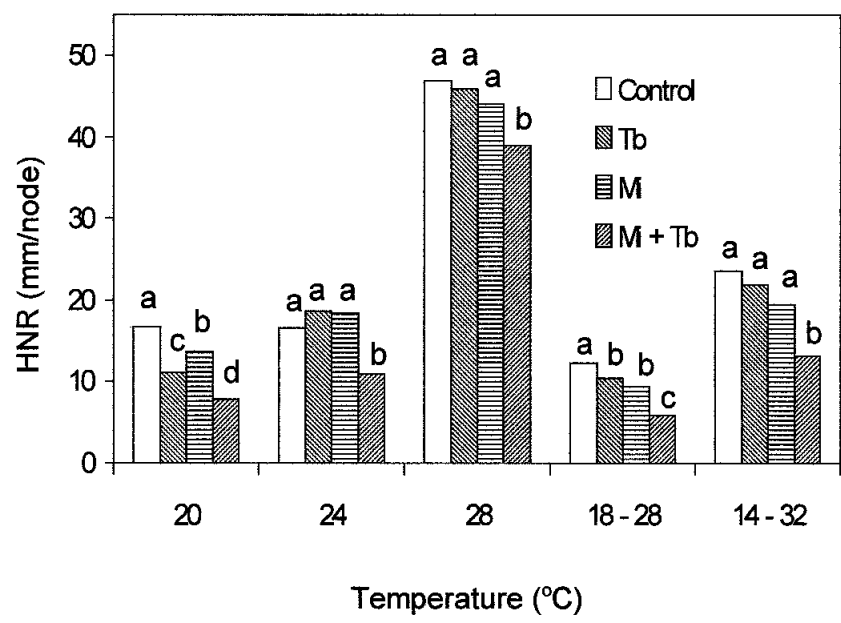

Fig. 1. Plant height-to-node ratio (HNR) (mm/node) for 42-day-old cotton plants grown in soil infested with Meloidogyne incognita (Mi) and Thielaviopsis basicola $(\mathrm{Tb})$ at different growth chamber temperatures. Data are the means of two trials with five replications each. Means within a group of bars followed by the same letter are not significantly different $(P \leq 0.05)$ according to Fisher's protected least significant difference test. remove soil, blotted dry, and weighed. Root systems were rated for disease severity on a scale of 1 to 5 , in which $1=0 \%, 2=1$ to $10 \%, 3=11$ to $25 \%, 4=26$ to $50 \%$, and $5=51$ to $100 \%$ of the root system discolored. The tap root was split to observe discoloration of the vascular tissue by $T$. basicola. Plant height-to-node ratio (HNR), measured from the cotyledonary node to the tip of the main stem terminal, was recorded for all plants. Nematode population densities were evaluated by extracting eggs from entire root systems in $0.05 \% \mathrm{NaOCl}$ (9) for $5 \mathrm{~min}$. Root systems were evaluated for nematode galling on a scale of 0 to 5 , in which $0=$ no galls per root system, $1=1$ to $2,2=3$ to $10,3=11$ to $30,4=$ 31 to 100 , and $5=>100$ galls per root system.

Statistical analyses were conducted with SAS (SAS Institute, Cary, NC) to evaluate treatment effects for the different temperature treatments and over experiments. Treatment means within a temperature were compared by Fisher's protected least significant difference test. Orthogonal contrasts to identify a significant synergistic interaction between the pathogens were conducted for plant HNR and plant weight and consisted of $T$. basicola or $M$. incognita alone versus the control and of $T$. basicola or $M$. incognita alone versus $M$. incognita $+T$. basicola.

Histology study. Inoculum and soil infestation were the same as described previously. Five seeds of the cv. Deltapine 50 were planted in pots and placed in a growth chamber with a 12-h photoperiod at $24^{\circ} \mathrm{C}$. Pots were separated by individual watering trays to prevent contamination and were bottom-watered. Noninfested pots served as controls. Pots were arranged in a completely randomized design.

Entire root systems were sampled at 14, 28, or 42 days and fixed in a formalin/acetic acid/alcohol solution (10) until use. Tissue samples were dehydrated in ethanol/tertiary butyl alcohol (10) and thermally embedded in Tissueprep2 compound (Fisher Scientific Co., Suanee, GA). Embedded tissue was sectioned at $10 \mu \mathrm{m}$ with a rotary microtome (Spencer Lens Co., Buffalo, NY). Serial sections were thermally mounted on glass slides with gelatin (Sigma Aldrich Inc., St. Louis) and the embedding compound removed with Hemo-De (Fisher Scientific Co.). Sections were stained using a modified Triarch quadruple stain, to exclude the use of xylene (5), and examined with a light microscope. Samples from treatments obtained 14 and 42 days after planting were replicated five times. Due to space restrictions, 28-day-old samples were replicated three,

TABLE 1. Fresh plant weight (g) of 42-day-old cotton plants in soils infested with Meloidogyne incognita and Thielaviopsis basicola at different growth chamber temperatures ${ }^{\mathrm{x}}$

\begin{tabular}{|c|c|c|c|c|c|c|c|}
\hline \multirow[b]{2}{*}{ Treatment } & \multicolumn{2}{|c|}{$20^{\circ} \mathrm{C}$} & \multirow{2}{*}{$\frac{24^{\circ} \mathrm{C}}{\text { Both trials }}$} & \multirow{2}{*}{$\frac{28^{\circ} \mathrm{C}}{\text { Both trials }}$} & \multicolumn{2}{|c|}{$18-28^{\circ} \mathrm{C}$} & \multirow{2}{*}{$\frac{14-32^{\circ} \mathrm{C}}{\text { Both trials }}$} \\
\hline & Trial 1 & Trial 2 & & & Trial 1 & Trial 2 & \\
\hline Control & $2.53 \mathrm{a}^{\mathrm{y}}$ & $2.86 \mathrm{a}$ & $2.28 \mathrm{a}$ & $3.85 \mathrm{a}$ & $2.67 \mathrm{a}$ & $2.34 \mathrm{a}$ & $3.32 \mathrm{a}$ \\
\hline T. basicola & $1.28 \mathrm{~b}$ & $2.33 \mathrm{~b}^{* \mathrm{z}}$ & $2.02 \mathrm{~b}$ & $3.92 \mathrm{a}$ & $2.27 \mathrm{a}$ & $2.20 \mathrm{a}$ & $3.01 \mathrm{a}$ \\
\hline T. basicola + M. incognita & $0.47 \mathrm{c}$ & $1.49 \mathrm{c}^{*}$ & $1.51 \mathrm{c}$ & $3.36 \mathrm{~b}$ & $0.85 \mathrm{~b}$ & $1.80 \mathrm{~b}^{*}$ & $1.71 \mathrm{~b}$ \\
\hline
\end{tabular}

${ }^{\mathrm{x}}$ Data are means of two trials with five replications, except where trial is noted.

${ }^{y}$ Means within the same column followed by the same letter are not significantly different $(P \leq 0.05)$ according to Fisher's protected least significant difference test.

${ }^{\mathrm{z}}$ Means between trials within the same temperature and pathogen treatment followed by * are significantly different $(P \leq 0.05)$ according to Fisher's protected least significant difference test.

TABLE 2. Root discoloration of 42-day-old cotton plants in soils infested with Meloidogyne incognita and Thielaviopsis basicola at different growth chamber temperatures $^{x}$

\begin{tabular}{|c|c|c|c|c|c|c|c|}
\hline \multirow[b]{2}{*}{ Treatment } & \multicolumn{2}{|c|}{$20^{\circ} \mathrm{C}$} & \multirow{2}{*}{$\frac{24^{\circ} \mathrm{C}}{\text { Both trials }}$} & \multicolumn{2}{|c|}{$28^{\circ} \mathrm{C}$} & \multirow{2}{*}{$\frac{18-28^{\circ} \mathrm{C}}{\text { Both trials }}$} & \multirow{2}{*}{$\frac{14-32^{\circ} \mathrm{C}}{\text { Both trials }}$} \\
\hline & Trial 1 & Trial 2 & & Trial 1 & Trial 2 & & \\
\hline Control & $0.00 \mathrm{c}^{\mathrm{y}}$ & $0.00 \mathrm{~d}$ & $0.02 \mathrm{c}$ & $0.04 \mathrm{~d}$ & 0.00 & $0.08 \mathrm{c}$ & $0.04 \mathrm{c}$ \\
\hline T. basicola & $5.00 \mathrm{a}$ & $3.96 \mathrm{~b}^{* \mathrm{z}}$ & $4.43 \mathrm{a}$ & $3.40 \mathrm{~b}$ & $2.64 \mathrm{a}$ & $3.02 \mathrm{~b}$ & $3.94 \mathrm{a}$ \\
\hline T. basicola $+M$. incognita & $4.88 \mathrm{a}$ & $5.00 \mathrm{a}$ & $4.62 \mathrm{a}$ & $4.58 \mathrm{a}$ & $2.82 \mathrm{a}^{*}$ & $4.58 \mathrm{a}$ & $4.54 \mathrm{a}$ \\
\hline
\end{tabular}

${ }^{\mathrm{x}}$ Root discoloration on a scale of 1 to 5 , in which $1=$ no root discoloration and $5=51$ to $100 \%$ of the root system discolored. Data are means of two trials with five replications, except where trial is noted.

${ }^{y}$ Means within the same column followed by the same letter are not significantly different $(P \leq 0.05)$ according to Fisher's protected least significant difference test.

${ }^{z}$ Means between trials within the same temperature and pathogen treatment followed by $*$ are significantly different $(P \leq 0.05)$ according to Fisher's protected least significant difference test. 
four, and five times for the control, T. basicola, and M. incognita + $T$. basicola treatments, respectively.

\section{RESULTS}

Temperature study. Plant HNR was reduced by the $M$. incog$n i t a+T$. basicola treatment for all temperature regimes compared with the control or with either pathogen alone (Fig. 1). When orthogonal contrasts were examined, $M$. incognita $+T$. basicola at $24^{\circ} \mathrm{C}$ reduced plant HNR compared with either pathogen alone $(P \leq$ 0.01 ), indicating a significant synergistic interaction.
A significant treatment by experiment interaction occurred for plant weight at $20^{\circ} \mathrm{C}$ and 18 to $28^{\circ} \mathrm{C}$. Total plant weight was reduced by $M$. incognita $+T$. basicola compared with all treatments for all temperatures, except for $M$. incognita alone at $28^{\circ} \mathrm{C}$ and for the first trial at 18 to $28^{\circ} \mathrm{C}$ (Table 1). Cotton plant weight was reduced significantly by $T$. basicola alone at 20 and $24^{\circ} \mathrm{C}$ in comparison to the control or $M$. incognita treatments. Plant weight was lower for plants from the first trial for $T$. basicola alone at $20^{\circ} \mathrm{C}$ and for M. incognita + T. basicola at 20 and 18 to $28^{\circ} \mathrm{C}$ compared with the second trial. Orthogonal contrasts indicated that an interaction occurred between $M$. incognita and T. basicola for all
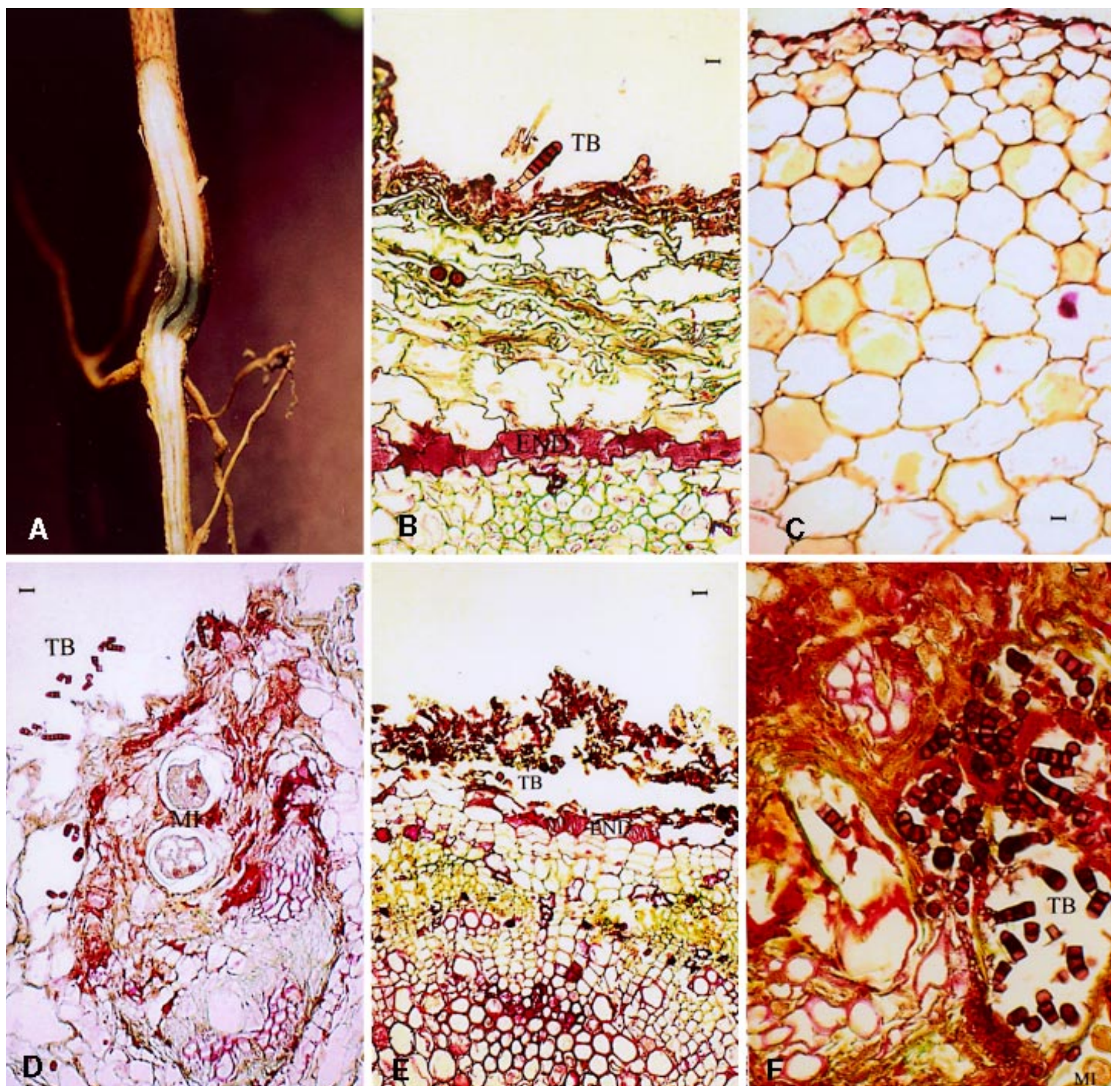

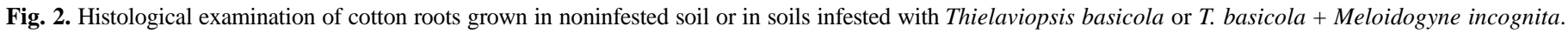

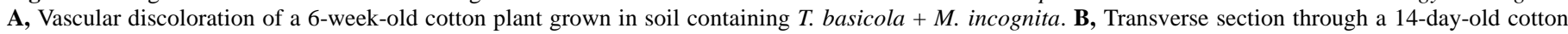

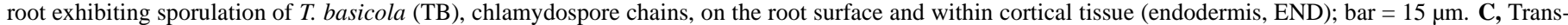

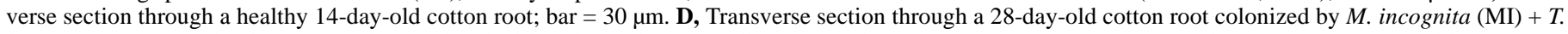

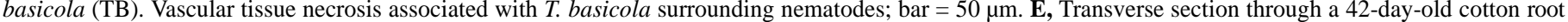

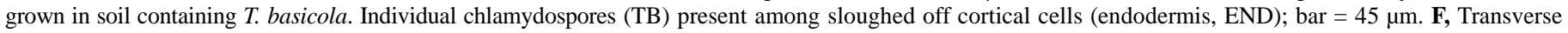

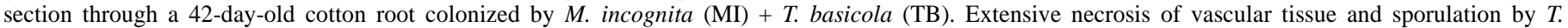
basicola; bar $=15 \mu \mathrm{m}$. 
temperatures, except $28^{\circ} \mathrm{C}$, resulting in significantly reduced plant weight $(P \leq 0.01)$.

A significant treatment by experiment interaction occurred for necrosis at 20 and $28^{\circ} \mathrm{C}$. Root discoloration for both treatments that included T. basicola was higher in all temperature regimes compared with the control or $M$. incognita treatments (Table 2). Root discoloration was greater for $M$. incognita + T. basicola than for $T$. basicola alone for the second trial at $20^{\circ} \mathrm{C}$, the first trail at $28^{\circ} \mathrm{C}$, and both trials at 18 to $28^{\circ} \mathrm{C}$. Discoloration of tap root vascular root tissue by $T$. basicola (Fig. 2A) ranged between $10 \%$ of the plants at $20^{\circ} \mathrm{C}$ to $0 \%$ at $28^{\circ} \mathrm{C}$. Discoloration was much greater for all $M$. incognita $+T$. basicola treatments across temperature regimes and ranged from $30 \%$ at $20^{\circ} \mathrm{C}$ to $54 \%$ at the 18 to $28^{\circ} \mathrm{C}$ regime. Discoloration of vascular tissue was not present for $T$. basicola alone at $28^{\circ} \mathrm{C}$; however, discoloration of vascular tissue for the $M$. incognita $+T$. basicola treatment occurred in $35 \%$ of the plants at $28^{\circ} \mathrm{C}$. Discolored vascular tissue for $M$. incognita + T. basicola treatments, upon microscopic examination, contained chlamydospores. Chlamydospores were not found in the vascular tissue of $T$. basicola treatments.

A significant treatment by experiment interaction occurred for root galling at 24 and 18 to $28^{\circ} \mathrm{C}$ and for the number of nematode eggs per plant at all temperatures, except 14 to $32^{\circ} \mathrm{C}$. However, root galling by and reproduction of $M$. incognita was reduced by T. basicola for all temperature treatments (Tables 3 and 4, respectively).

Histology study. Fourteen days after planting, roots grown in soil containing $T$. basicola exhibited sporulation and chlamydospore chains on the root surface and within cortical tissue (Fig. 2B). In contrast to roots not colonized by $T$. basicola (Fig. 2C), the thickness of the cortical tissue for T. basicola-colonized roots was reduced. The fungus was not observed in root vascular tissue at 14 days for any treatments. Cortical tissue from root-knot-infected roots was similar to roots from the control.

Twenty-eight days after planting, cortical cells from roots grown in soils containing T. basicola alone were collapsed and cells were difficult to discern. At 28 days, roots receiving both pathogens were markedly different in appearance from those treated with either pathogen alone. Serial sections of roots revealed fungal sporulation inside the root vascular tissue, and vascular necrosis caused by $T$. basicola was associated with the presence of the nematode (Fig. 2D). Nematode reproduction was not observed when T. basicola colonized tissue near the nematode or nematode feeding site. However, nematode development varied, with some females being reproductively active and laying eggs in the absence of fungal colonization of plant tissue.

Forty-two days after planting, plants grown in soil with T. basicola alone exhibited normal secondary root tissue growth. Individual chlamydospores were observed among cortical tissue debris, and none of the roots examined contained fungal sporulation within the vascular tissue (Fig. 2E). Forty-two-day-old roots that were from soil infested with both pathogens were distorted and exhibited considerable tissue necrosis including the vascular tissue (Fig. 2F). Extensive $T$. basicola sporulation was evident both inside necrotic vascular tissue and in xylem vessels.

\section{DISCUSSION}

Successful cotton production in the Mississippi River Delta often depends on earliness of crop maturity; as a result, producers commonly plant into cool soils, conditions that favor black root rot development (17) and may result in increased black root rot occurrence and greater population levels of the pathogen. Black root rot has recently been reported to be involved in an interaction with the root-knot nematode on 'Upland' cotton (21). This interaction results in plant mortality, delayed maturity, and reduced productivity of the surviving plants. Increased plant mortality was observed at 42 days in this study where both pathogens were present compared with the treatments of either pathogen alone or the control at 24,28 , and 18 to $28^{\circ} \mathrm{C}$, except for M. incognita $+T$. basicola compared with $T$. basicola alone at $24^{\circ} \mathrm{C}$ (data not shown), paralleling field observations. However, too few plants were included in this study to accurately define the effects of temperature and both pathogens on plant survival.

Plant HNR has been a sensitive parameter for measuring damage from these pathogens to cotton in previous studies (21). In this study, plant HNR was reduced by $M$. incognita $+T$. basicola over all temperature treatments, with the severity of reduction greatest at $24^{\circ} \mathrm{C}$ and the two cyclic temperature regimes. Vascular discoloration in plants from $M$. incognita $+T$. basicola treatments was observed frequently, and examination under the light microscope often revealed T. basicola chlamydospores. Symptomatic vascular tissue from the treatments with T. basicola alone, when it occurred, was typically a localized brown to tan region without the presence of chlamydospores. However, these roots were still rated as having vascular discoloration. The observation of $T$. basicola in the vascular tissue in the presence of $M$. incognita is consistent with previous observations of cotton roots from production fields

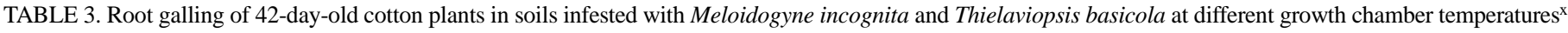

\begin{tabular}{|c|c|c|c|c|c|c|c|}
\hline \multirow[b]{2}{*}{ Treatment } & \multirow{2}{*}{$\frac{20^{\circ} \mathrm{C}}{\text { Both trials }}$} & \multicolumn{2}{|c|}{$24^{\circ} \mathrm{C}$} & \multirow{2}{*}{$\frac{28^{\circ} \mathrm{C}}{\text { Both trials }}$} & \multicolumn{2}{|c|}{$18-28^{\circ} \mathrm{C}$} & \multirow{2}{*}{$\frac{14-32^{\circ} \mathrm{C}}{\text { Both trials }}$} \\
\hline & & Trial 1 & Trial 2 & & Trial 1 & Trial 2 & \\
\hline M. incognita & $4.57 \mathrm{a}^{\mathrm{y}}$ & $4.89 \mathrm{a}$ & $4.52 \mathrm{a}$ & $4.72 \mathrm{a}$ & $4.64 \mathrm{a}$ & $4.80 \mathrm{a}$ & $4.01 \mathrm{a}$ \\
\hline T. basicola + M. incognita & $1.91 \mathrm{~b}$ & $1.70 \mathrm{~b}$ & $3.05 \mathrm{~b}^{* \mathrm{z}}$ & $3.86 \mathrm{~b}$ & $1.57 \mathrm{~b}$ & $3.30 \mathrm{~b}^{*}$ & $2.40 \mathrm{~b}$ \\
\hline
\end{tabular}

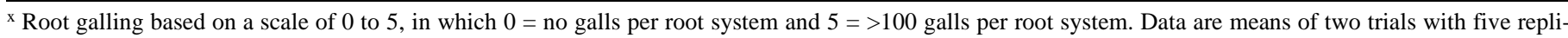
cations, except where trial is noted.

y Means within the same column followed by the same letter are not significantly different $(P \leq 0.05)$ according to Fisher's protected least significant difference test.

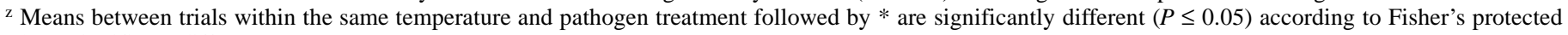
least significant difference test.

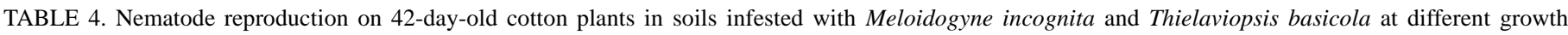
chamber temperatures ${ }^{\mathrm{x}}$

\begin{tabular}{|c|c|c|c|c|c|c|c|c|c|}
\hline \multirow[b]{2}{*}{ Treatment } & \multicolumn{2}{|c|}{$20^{\circ} \mathrm{C}$} & \multicolumn{2}{|c|}{$24^{\circ} \mathrm{C}$} & \multicolumn{2}{|c|}{$28^{\circ} \mathrm{C}$} & \multicolumn{2}{|c|}{$18-28^{\circ} \mathrm{C}$} & \multirow{2}{*}{$\frac{14-32^{\circ} \mathrm{C}}{\text { Both trials }}$} \\
\hline & Trial 1 & Trial 2 & Trial 1 & Trial 2 & Trial 1 & Trial 2 & Trial 1 & Trial 2 & \\
\hline M. incognita & $2.10 \mathrm{a}^{\mathrm{y}}$ & $3.56 \mathrm{a}^{* \mathrm{z}}$ & $4.32 \mathrm{a}$ & $4.88 \mathrm{a}^{*}$ & $4.85 \mathrm{a}$ & $4.79 \mathrm{a}$ & $4.47 \mathrm{a}$ & $4.74 \mathrm{a}$ & $4.48 \mathrm{a}$ \\
\hline$T$. basicola $+M$. incognita & $1.95 \mathrm{~b}$ & $2.53 \mathrm{~b}$ & $2.72 \mathrm{~b}$ & $4.02 \mathrm{~b}^{*}$ & $3.82 \mathrm{~b}$ & $4.17 b^{*}$ & $2.25 \mathrm{~b}$ & $4.08 \mathrm{~b}^{*}$ & $3.08 \mathrm{~b}$ \\
\hline
\end{tabular}

${ }^{\mathrm{x}}$ Number of eggs per plant $\log$-transformed $\left(\log _{10}+1\right)$. Data are means of two trials with five replications, except where trial is noted.

y Means within the same column followed by the same letter are not significantly different $(P \leq 0.05)$ according to Fisher's protected least significant difference test.

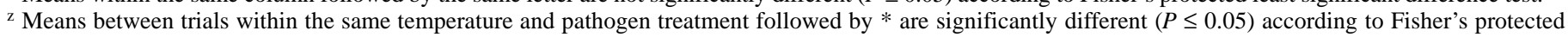

least significant difference test. 
and microplot studies that were known to contain both pathogens (data not shown).

These observations suggest that the presence of the nematode physically disrupts the continuity of the endodermis that normally functions as a barrier to further fungal invasion into the root. Vascular tissue colonization by $T$. basicola may enhance root dysfunction caused by the nematode (12), causing increased seedling mortality in grower fields under specific environmental conditions. Mauk and Hine (14) indicated that 'Upland' cotton grown at low temperatures in field soils naturally infested with high populations of $T$. basicola may contain the fungus in the vascular tissue. The presence or absence of the nematode was not reported. Studies by Mathre et al. (13) also mention colonization of plant vascular tissue in soils with very high $T$. basicola populations, although it was not apparent what inoculum levels were used in their studies. Most reports, however, indicate that the pathogen is limited to cortical tissue in $G$. hirsutum $(13,22)$ and a characteristic diagnostic feature of the disease is white, healthy vascular tissue beneath necrotic cortical tissue.

This study parallels previous studies in reporting a reduction in nematode fecundity and root galling severity when $T$. basicola also was present (21). After initiation of nematode-induced giant cells, the nematode becomes increasingly sedentary and is incapable of relocation. Destruction of the giant cells by $T$. basicola likely would result in the death of the nematode, accounting for the reduction in fecundity documented in these studies. This is consistent with the observations made of 28-day-old roots containing $M$. incognita + T. basicola.

Interactions between pathogens have often been described based on the level of disease on the host plant. These interactions are often defined as synergistic or additive (6). Interactions are considered additive when the level of disease or damage to the host is equal to the sum of damage by both pathogens on separate hosts. Synergistic interactions occur when the level of disease or host damage caused by the pathogens together is greater than the sum of both pathogens on separate hosts. Detailed research focused on the underlying mechanisms for the relationship or the influence of the environment are lacking for many disease interactions. Under these definitions, the interaction between $M$. incognita and $T$. basicola for a number of parameters including plant HNR, rate of plant maturity, and plant architecture have been shown to be synergistic (21).

Histological observations suggest that $M$. incognita infection of cotton seedling roots facilitates entry of $T$. basicola into vascular tissue, tissue that is not normally accessible to the fungus in G. hirsutum. In addition, infection by the nematode appears to allow seedlings to be damaged by the fungus across a range of soil temperatures that are normally suboptimal for T. basicola. This is in contrast to other root-knot nematode-fungal interactions on cotton in which temperature favors both pathogens, as for Rhizoctonia solani (3), or with fungi that are able to colonize tissue without the nematode, as with Fusarium wilt (20). This study also implies that root-knot nematode management in cotton production fields may be a primary means to minimize the damage caused when these two pathogens are found together under cool temperature conditions.

\section{ACKNOWLEDGMENTS}

Published with the approval of the director, Arkansas Agricultural Experiment Station, Fayetteville.

\section{LITERATURE CITED}

1. Bridge, J. 1992. Nematodes. Pages 331-353 in: Cotton Diseases. R. J. Hillcocks, ed. CAB International, Wallingford, United Kingdom.

2. Candole, B. L., and Rothrock, C. S. 1997. Characterization of the suppressiveness of hairy vetch-amended soils to Thielaviopsis basicola. Phytopathology 87:197-202.

3. Carter, W. W. 1975. Effects of soil temperature and inoculum levels of Meloidogyne incognita and Rhizoctonia solani on seedling disease of cotton. J. Nematol. 7:229-233.

4. Carter, W. W. 1982. Influence of soil temperature on Meloidogyne incognita resistant and susceptible cotton, Gossypium hirsutum. J. Nematol. 14:343-346.

5. Daykin, M. E., and Hussey, R. S. 1985. Staining and histopathological techniques in nematology. Pages 39-48 in: An Advanced Treatise on Meloidogyne. Vol. II: Methodology. K. R. Barker, C. C. Carter, and J. N. Sasser, eds. North Carolina State University Graphics, Raleigh.

6. Evans, K., and Haydock, P. P. J. 1993. Interactions of nematodes with root-rot fungi. Pages 104-133 in: Nematode Interactions. M. W. Kahn, ed. Chapman and Hall, London, United Kingdom.

7. Farr, D. F., Bills, G. F., Chamuris, G. P., and Rossman, A. Y. 1989. Fungi on Plants and Plant Products in the United States. The American Phytopathological Society, St. Paul, MN.

8. Hood, M. E., and Shew, H. D. 1997. Reassessment of the role of saprophytic activity in the ecology of Thielaviopsis basicola. Phytopathology 87:1214-1219.

9. Hussey, R. S., and Barker, K. R. 1973. A comparison of methods of collecting inocula of Meloidogyne spp., including a new technique. Plant Dis. Rep. 57:1025-1028.

10. Jenson, W. A. 1962. Botanical Histochemistry, Principles and Practice. W. H. Freeman and Company, San Francisco, CA.

11. Kirkpatrick, T. L., Barham, J. D., and Bateman, R. J. 1992. Incidence of plant-parasitic nematodes in cotton fields in Arkansas. Pages 57-62 in: Proc. Cotton Res. Meeting, 1992. D. M. Oosterhuis, ed. Ark. Agric. Exp. Stn. Spec. Rep. 158.

12. Kirkpatrick, T. L., van Iersel, M. W., and Oosterhuis, D. M. 1995. Influence of Meloidogyne incognita on the water relations of cotton grown in microplots. J. Nematol. 27:465-471.

13. Mathre, D. E., Ravenscroft, A. V., and Garber, R. H. 1966. The role of Thielaviopsis basicola as a primary cause of yield reduction in cotton in California. Phytopathology 56:1213-1216.

14. Mauk, P. A., and Hine, R. B. 1988. Infection, colonization of Gossypium hirsutum and G. barbadense, and development of black root rot caused by Thielaviopsis basicola. Phytopathology 78:1662-1667.

15. Nan, Z. B., Long, P. G., Skipp, R. A., and Hopcroft, D. H. 1992. Microscopy of invasion of red clover roots by Trichocladium basicola, and effects of benomyl and prochloraz. Plant Pathol. 41:449-461.

16. Robbins, R. T., Riggs, R. D., and Von Steen, D. 1989. Phytoparasitic nematode surveys of Arkansas cotton fields, 1986-88. J. Nematol. 21(suppl.):619-623.

17. Rothrock, C. S. 1992. Influence of soil temperature, water, and texture on Thielaviopsis basicola and black root rot of cotton. Phytopathology 82:1202-1206.

18. Rothrock, C. S. 1997. Prevalence and distribution Thielaviopsis basicola. Pages 75-77 in: Proc. Beltwide Cotton Conf., 1997. D. J. Heber and D. A. Richter, eds. National Cotton Council of America, Memphis, TN.

19. Rothrock, C. S., and Kirkpatrick, T. L. Prevalence of Thielaviopsis basicola in cotton soils in Arkansas and its association with the root-knot nematode. In: Proceedings of the Second World Cotton Research Conference. Scientific Committee of the WCRC-2. In press.

20. Starr, J. L., Jeger, M. J., Martyn, R. D., and Schilling, K. 1989. Effects of Meloidogyne incognita and Fusarium oxysporum $\mathrm{f}$. sp. vasinfectum on plant mortality and yield of cotton. Phytopathology 79:640-646.

21. Walker, N. R., Kirkpatrick, T. L., and Rothrock, C. S. 1998. The interaction between the root-knot nematode (Meloidogyne incognita) and black root rot (Thielaviopsis basicola) on cotton (Gossypium hirsutum). J. Nematol. 30:415-422.

22. Watkins, G. M., ed. 1981. Compendium of Cotton Diseases. The American Phytopathological Society, St. Paul, MN. 